\title{
Methods of teaching in Islam and incorporating certain ideas into the teaching of the modern medical Science in India: Some thoughts and some observations
}

\author{
N Ganguly N. ${ }^{1 *}$, Phukan Ray R. ${ }^{2}$
}

DOI: https://doi.org/10.17511/ijmrr.2019.i06.18

\footnotetext{
1* Narendra N Ganguly, Associate Professor, Department of Surgery, Jorhat Medical College, Jorhat, Assam, India.

2 Rituparna Phukan Ray, Associate Professor, Department of Pharmacology, Jorhat Medical College, Jorhat, Assam, India.
}

The fast progress of the Medical Science as well as introduction of newer technologies makes Teaching in Medical science challenging. It is difficult to teach the Medical students in all the aspects of medical science and produce good, well learned, treating doctors within a span of four and a half years. Introduction of non treating branches in the final MBBS, as clinical subjects, has compounded the problem. The paucity of time to teach the treating branches in the final year, has caused confusion amongst the mind of the teachers of the treating branches. In such a scenario, we thought that it is worth to look into the ancient methods of teaching, which are still relevant in today's world. The present activities of the MCI, is confusing. The effort of re teaching the old and senior teachers, how to teach, is failing. This necessitates re-look into the past to introduce new ideas into medical education methodology. Here we look into the system of teaching followed by the Islamic faith. Islamic scholars spread the light of knowledge to the west. They were voracious observers, readers as well as energetic writers. These scholars took the wisdom of the east to the wild of the west. Although the journal publications on the subject of Islamic methodologies are sparse, the materials available are very useful in providing an insight to the teaching methods in Islam. Following the disciplined methods, the students learn without fail and spread the gist of knowledge in the society around. It is worth to look into the methods of the teaching in this one and half millennia old system and see if some input can be made into the modern methodology of teaching in the modern Medical Education delivery in India. The available literature on the subject sheds enough light to the teaching methods in Islam. Many of these steps can be incorporated in the teaching methodology in the Medical education in India.

Keywords: Islam, Education, Medical, Treating and Non-treating Teachers

Corresponding Author

Narendra N Ganguly, Associate Professor, Department of Surgery, Jorhat Medical College, Jorhat, Assam, India.

Email: drganguly@yahoo.com
How to Cite this Article

To Browse

Ganguly NN, Ray RP. Methods of teaching in Islam and incorporating certain ideas into the teaching of the modern medical Science in India: Some thoughts and some observations. Int J Med Res Rev. 2019;7(6):568-573.

Available From

https://ijmrr.medresearch.in/index.php/ijmrr/article/

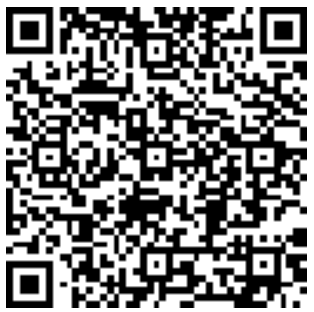
view/1099

Manuscript Received 2019-10-16

Conflict of Interest No

(c) 2019 by Narendra N Ganguly, Rituparna Phukan Ray and Published by Siddharth Health Research and Social Welfare Society. This is an Open Access article licensed under a Creative Commons Attribution 4.0 International License https://creativecommons.org/licenses/by/4.0/ unported [CC BY 4.0]. 


\section{Introduction}

Education is the desirable and comparatively permanent change of behavior. Education derives from Latin word educare, educere or educatum. The word educare also means rearing where educere means to bring out and educatum means to teach [1].

Educating the Medical students in the present time has become a challenging task. The rapid growth of all aspects of the subjects, introduction of technology, introduction of Artificial intelligence have made teaching the subjects to maintain an optimal standard of education, a difficult task. To address the recent increase in the complexity of the delivery of healthcare to the masses, the MCI has brought in certain policy changes in the Education Delivery system in the Medical Science. The AETCOM module, as well as the introduction of various short courses in the teaching methodology, is introduced to prepare a system change in the medical education sector. With the introduction of the newer ideas it is expected that the entire senior and the older teachers of the Medical Science will be taught to upgrade their teaching skills for a better delivery and standard.

All teachers of the Medical Education are directed to undergo such trainings. In such a revolutionary scenario we thought to look into the treasures of the ancient teaching methods prevalent in the world. This will lead us to understand how vast amount of literatures were taught to the students and made them capable of retaining the education and to subsequently spread the knowledge in the society. Here we followed texts and literatures available on the Islamic way of teaching [2-9] and tried to find out similarities with the present-day requirements in the field of medical education.

\section{Review of Literature}

The available literatures in the subject of teaching methods in Islam are sparse. The few major articles gathered are of course good and give an insight into the ancient way of teaching. It may also be remembered that education is not an absolute term. It is expressed in many ways in a society. It may be in the field of behavioral, cultural or on the economic front. It may show its presence in the growth of an individual or the society as a whole in both the philosophical as well as the scientific outlook with social and spiritual behavior.
In other words, education denotes the holistic development of the mind of individuals for the betterment of the society. Socrates interpreted that, education is the mean that helps in searching the truth.

Aristotle interpreted it as, a process necessary for the creation of sound mind in a sound body. It is also understood that Education is the process of learning, or the acquisition of knowledge, skills, values, beliefs, and habits. Educational methods include storytelling, discussion, teaching, training and directed research. Education frequently takes place under the guidance of the teachers, but students may also educate themselves in a collaborative way $[1,7-12]$.

During the time Islam was borne, India was a great civilization of over six thousand years with a solid educational system. The Society was classified as per the profession of an Individual. This Classification of the populace by their professions was called "Varnashrama". By that practice, the Brahmans were the only sect, who took up the burden of Teachings of the individuals. This discrimination according to profession extended to birth in that particular sect.

In such a backdrop appearance of Islam with no division was a welcome change in the world. The Prophet, at the leadership of this new way of life was a simple man and was orphaned in his early life. His utterances gave solace to people. Soon followers of his teachings spread like wildfire. His sermons started attracting more and more of the richer people and from far and far countries. They took it upon themselves to spread his messages far and wide. By far this is the perfect example of a teaching method or what should be an ideal method of teaching.

Generally the majority of outstanding teachers of Islamic education are using questionnaires, group discussions, student-teacher discussions, reciting verses from the Quran, demonstrations, motivation, memorizing individually, memorizing in groups and practice in their teaching. However, storytelling and brainstorming techniques are used more frequently by excellent Islamic Education teachers in present days.

In addition, the teaching session will be successful with the selection of teaching methods and techniques that can have a profound impact not only on the understanding of students, but also affecting and touching their heart. 
In this way students will stay focused and be able to remember the lessons faster and better.

In the early years of Islam during the prophetic era Islamic method changed and improved the existing education system. First, it changed the system locally and thereafter far and wide with the spread of the Religion. Education was considered a revolution by the Prophet Muhammad. He was not only the preacher of a new religion and the head of the new community.

He was also a very good teacher as well as a promoter of learning. Islam is a knowledge-centric religion, a religion of the holy Book. The mosques were the place of worship; these also were the first schools in Islam and the main place for spreading Islamic education.

The early Muslims were devoted to the cause of education. Although they followed an oral tradition, they began to seek knowledge with great enthusiasm. They were inspired by the effective methods and techniques of teaching of Prophet Muhammad. He used every possible method to convey knowledge to the people [1,10-15].

Our current education system is destroying creativity. Many disapprove of our current education system and believe that it is holding the students back. The statement can be applied to the present MCI activity in the Medical Education improvement system [16]. To develop the existing education system, it is important to know about the teaching methods and techniques and early educational activities during the era of Prophet Muhammad.

\section{Definition of Education in Islam}

Arabic language defines three etymological meaning of education.

01. Talim- from the root alima (to know, to be aware, to perceive, to learn) which is used to denote knowledge spread through instruction and teaching.

02. Tarbiyah from the root raba (to increase, to grow, to rear) means a state of spiritual and ethical attention in accordance with the will of God. And

03. Tadib from the root aduba (to be cultured, refined, well-mannered) suggests development of good social behavior. What is meant by good social behavior requires a deeper understanding of the Islamic conception of human being.
It is stated in the Quran, "Allah will exalt those who believe among you, and those who have knowledge, to high ranks. Allah is informed of what he ye do". Followers of Islam believe that Allah created humanity and commanded that they seek knowledge in order to become stronger in their faith. The importance of education has been emphasized repeatedly in the Quran. Verse 20/114 says, "My Lord! Increase me in knowledge."

This verse indicates that whatever we know is limited as we need to keep asking the God to increase knowledge in the mind. Therefore, a follower of Islam should be seeking more knowledge (ilm). The Quran treats knowledge as a means to reaching iman (faith) for all Muslims, males and females, to becoming true believers. Therefore, in the Quran and hadith, the importance of education is of paramount importance. In Islam seeking education is a must, and that knowledge is considered to be the path towards greater closeness to the God.

Islam emphasized two types of knowledge,

01. Revealed and

02. Earthly - i.e., revealed knowledge that comes straight from God and earthly knowledge, which is, discovered by human beings. Islam considers both of importance and directs, both men and women, to seek knowledge.

An interesting tradition says: "Who possesses a slave girl and teaches her and teaches her well and trains her and trains her well, and then liberates her to marry her as a regular wife, he shall have double merit".

The Prophet's teaching Methods and Techniques, which subsequently became the teaching methods in the spread of education in Islam

(1) Freedom of Research- Generating interest in self learning

(2) Giving Short Talks after prayers

(3) The Prophet Used to Criticize the Behavior Not the Agent- it was indeed a very effective Method of Observation and Correction of faults.

(4) Men and Women were taught equally.

(6) Education through Story Telling

(7) Teach Through Gradualism:

(8) Education through Applied Lessoning and reasoning 
(9) Teach by Asking Questions

(10) Teaching with use of Evidence

(11) Method of Pledge

(12) Method of Spreading Knowledge to Others

(13)Education through Accompanying the Educator for Some Time- (Apprenticeship?)

(14) Diagrammatic Representation

(15) Rewarded and Appreciated Positive Behaviors

(16) No Student Left Behind- Equal importance to all the students.

(17) Method of Memorization- The most effective and strict method of all

(18) Examples Suitable to the Topic

(19) Teach by Practice

(20) Using Oaths for Emphasis

(21) Method of Reading

(22) Method of Writing

(23) Speaking to People According to Their Level Communication and Attitude?

(24) Comparing Things

(25) Give Time for Rest So as Not to Over Burden Students with study

(26)Making Physical Contact When SpeakingCommunication and Attitude?

(27)Teach People According to Their Natures and Customs- Customization according to the Student background

(28) Use Gestures While Talking- Body Language?

(29) Repetitions of subject taught- Revision Classes?

(30) Using Anger- Communication and Attitude?

Strictness as well as regular and severe punishment was the driving forces behind the success of the teaching method in the Islamic tradition of teaching. All the students, be it a son of a king or a commoner were treated by the teachers with the same strictness. Physical punishments were used rampantly. It used to cause injury at times. Students, found with bad behavior and negligent to studies were punished and detained.
An example can be found in the following story, Abu Merriam, the educator of al-Amin and al-Mamun, once caned them so severely that the arm of one of the pupils was injured. The boy went home crying and showed his injury to his father and complained. The teacher was summoned. He was asked to explain the injury.

The teacher replied that the child is very mischievous and sly. He won't study and won't let others study in the class too. He needed to be punished. On hearing this, the King became angry and said, "if you think it is necessary then you may kill him. If he does not behave and learn to your satisfaction, then you may kill him. He better be dead than dull."

Fathers used to say to the teachers, "Your share is the flesh of our son, while ours is the bones."From these stories it becomes evident that the Islamic method of teaching was quite harsh. Punishment was the mainstay of infusing Discipline. In addition the bond between the followers of Islam created was very strong.

A Muslim is related to different people in three different ways:

01. First, he is related to his family members;

02. Secondly, to his relatives; and

03. Thirdly and finally, to other Muslims in the bond of religious brotherhood known as the Muslim Ummah.

All Muslims are taught strictly that they are related to one another through Islam, and this relationship is known as the "Islamic Brotherhood". Allah says in the Quran, "Indeed the believers are brothers." (49:10)

\section{Discussion}

Considering the above information some thoughts arise. Certain methods described in the Islamic way of teaching, initiated by the prophet Muhammad can be utilized to teach in the present-day Medical education in the Medical Colleges or in the Institutes [1-6]. The following are evident from the review of the literatures that, First, the Teaching method was very effective.

The thirty pointers prove it beyond doubt. Secondly, since the students were punished severely, they were compelled to learn. Thirdly, the teachers were inspired by the Prophet, so they were leading with example. 
Fourthly, having one book to guide all had its advantage, and Fifthly, to create a brotherhood. A strong brotherhood among the medical students and the treating doctors. This will be a good quality during the time of Crises [1-6].

Qualities and responsibilities of the teachers were also clearly defined in the Islamic methods of Teaching. During the period of the Prophet, the place of a teacher in the scheme of education was very important. The teachers were taught by the Prophet himself and had the purity of character, of thoughts and were generous. They kept keen eyes on progress of the students. Especially they were serious about the obeying of the rules. Some thoughts and observations become evident when these facts are analyzed with an aim to incorporate the methods in the modern teaching methods of Medical science. So far Islamic way of teaching has spread far and wide and is spreading rapidly. There must be some philosophy for its success in the present day world of conflicts.

The following points can be appreciated clearly from analyzing the above material. First, the quality of the teachers. The primary aim of the Medicos is to become treating branch practitioners. The present Faculty development program under the Medical Council of India is probably biased and hence flawed. The qualification criteria to become a teacher of the teachers in the nodal centers for the faculty development evidently show the dilution of the most important constituent of the medical education, the quality of the teachers.

A teacher from the non treating Departments with a fellowship of few months, a diploma, a so calledadvanced training in Medical Teaching with very short institutional contact will be considered a faculty of a nodal centre. Even authors of few papers on education are considered as eligibility criteria for the teachers of the teachers in such nodal centers of the Medical Education Department. The MCI guideline is surprisingly silent about those teachers in the non treating branches of the medical colleges who are not from the MBBS stream. Will they be teaching the teachers of the treating branches how to treat too? [16]. The aim of introducing the AETCOM (Attitude, Ethics and Communication) module is with good intention, but it is difficult to comprehend how a teacher from the non treating branch, with no experience in facing patients, will teach Attitude, ethics and communication to the teachers of the treating branches.
Saying this, it does not mean that the non treating teachers will not try their best; they are great teachers in their own non treating subjects. They will theoretically teach everything in details.

The capability of the Teachers must be given due importance as in the Islamic method [7-9]. To raise the standard of treatments, all the commanding positions in the Medical Universities, Medical Institutions, the Education units, Regional Centers and Nodal Centers should be headed by a faculty from the Departments capable of treating.

Faculties who face patients in Outdoors and emergencies, who are regularly facing mobs, facing deaths, facing surgeries and facing disasters, should be involved in the leadership positions. Teachers from these departments will be able to teach the other teachers about the expectation of the society from the treating Doctors [16].

A strict verbal approach like memorizing certain basics, Mnemonics, Charts, and Numbers must be made compulsory to the medicos. These will come handy in emergency situations. It has to be strict and the students pass or fail must be related to this important critical medical knowledge. Here application of Mentorship will come handy. The mentors can take charge of a batch of students and get them memorize the lists.

The Non Treating Teachers will be the most important constituent of this part of Medical Education.

Arranging more debates as well as question and answer classes. The students should take active participation in this. Ranks and marks can be made to relate to these classes. These classes and sessions can incorporate all the branches related to an organ or a disease. The students must take active part in arranging and completion of this part. The teachers from the non treating branches must assist in this stage actively under the guidance of the treating branch teachers.

Use of logics. We seem to have forgotten the past. The third year students used to be very innovative. They guided quite a few epoch making discoveries in the medical science. Students should be taught to challenge the teachers with their new found knowledge in every step of the treatment processes. This habit must be stimulated once the students complete their Anatomy, Physiology and the Biochemistry courses. 
Attitude and way to communicate with the patients and attendants as well as breaking bad news must be taught well with the light of body language. Touching, showing sympathy or anger can be used to effectively dousing the tension. These cannot be taught by theory. These are observed and learnt by the students [9-14].

Story telling as well as giving examples while dealing with the patients and attendants, so that the expectations remain within reality may be used [15].

Discourses in the form of theory classes must be utilized more. The main area where Islamic way of teaching became so successful is the Sermons. These are equivalent to the theory classes. We seem to have forgotten the use of the Theory classes. The present AETCOM module and teaching the teachers by the departments of Medical Education, led by a teacher from the non treating branch, is with good intention but would probably ruin the teaching of the students in the Medical Colleges in its present set ups. Revision classes as well as Theory classes should be utilized more in the medical education system today. In addition if some kind of compulsion were put upon the students, it would yield good results.

\section{Conclusions}

The method of teaching of Prophet Muhammad and the subsequent spread of Islamic civilization tells us the effectiveness of the teaching methods of the Islam. Illiterates were made to learn to read and write effectively.

The strictness was uniform to all. A son of King and one of the commoner were taught with the same effectiveness. Punishment, compulsion to learn, keeping oaths were used regularly. As a result, in a small time the Spread of Islam led to the spreading of the civilization in the west.

Incorporating some of these values in the present medical education teaching system, should help raising the standard of the medical education delivery system in India. The process of teaching in the present day seems to be wrong.

Having one book, learning first from the book and then from the apprenticeship sound better. The students need to have a set of books to follow. The teachers must also be well conversant with those books.
Strictness as well as the attitudes and communication must be more strongly incorporated. As Islam says, Not knowing is sin, the same principle must be incorporated in the present-day medical education system. Primarily, the policy changes must be guided by the proper treating Doctors only. Otherwise, the improvements will not be there. The teachers of the medical colleges are taking the trainings just to stay in the service. It has already become a tick mark in their resume. Very few are actually utilizing the new installed system of teachings. But of course, some must have been benefitted from it. The time has come to look back to go forward.

Disclaimer: All the views, thoughts, and opinions expressed in the text belong solely to the authors, and not necessarily to the Journal. The Journal does not endorse Authors views published in the paper. The paper published does not intend to hurt religious sentiments of any individual, group or community.

\section{Reference}

01. Md Mizanur Rahman. Education, Teaching Methods and Techniques in the Early Years of Islam During the Era of Prophet Muhammad (SAW). IJRDO-Journal of Business Management. 2018;4(2)1-22.

[Crossref]

02. Atique TB. Importance of Education in the Light of Islam- An Overview. Jagannath University J Arts. 2012;2(1)192-193.

[Crossref]

03. Ali M. The Concept of Education in Islam, A Thesis of the Department of Management Science. University of Wah, Pakistan. 2015;3-4. Available at [Article] [Crossref]

04. Khalid S. Karatun Allo- The Islamic System of Elementary Education in Hausaland. Cited 2019. Available at [Article] [Crossref]

05. Dewey John, Democracy and Education, The Middle Works, 1899-1924; 1980. Edited by Jo Ann Boydston, Associate Textual Editors Patricia $\mathrm{R}$ Baysinger and Barbara Levine With an Introduction by Sidney Hook. Carbondale and Edwardsville- Southern Illinois University Press, London and Amsterdam. Vol- 9;1916.

[Crossref] 
06. Selasa. Islamic Education at the Holy Prophet Muhammad Saw Period. updated 2012 Aug; Cited Nov. 2019.

[Internet] Available at [Article] [Crossref]

07. Shah S D. Prophet Muhammad's Method of Teaching. Bijaksana TnC [Internet]. 2009; cited 2019; Chennai.

Available at [Article] [Crossref]

08. Shaarawy K. The Teaching Methods of the Prophet Muhammad(pbuh). Updated 2014 Jan 24; Cited 2019 Nov.

Available at [Article] [Crossref]

09. Shareef MA. 21 Teaching Methods of Prophet. Available at [Article] [Crossref]

10. Muhammad Hamidullah and His Pioneering Works on Islamic Economics Islahi, Abdul Azim Islamic Economics Institute, King Abdulaziz University, Jeddah, KSA. 2016.

Available at [Article] [Crossref]

11. Maliki SMAA. The Prophetic Way of Teaching [Internet]. Updated 2014 May 16;Cited 2019 Nov.

Available at [Article] [Crossref]
12. Gultekin V. The Educational Methods of Our Prophet (PBUH), The Pen Magazine. [Internet] Updated 2012; cited 2019 Nov.

Available at [Article] [Crossref]

13. Khalediy K A. Education and Methods of Teaching in Islam in the Era of Az-Zarnooji, Almajma'a. Al-Qasemi Arabic Lang Acad. 2000;34;23-24.

[Crossref]

14. Khamis $M H$, Salleh $M J$. The Philosophy and Objectives of Education in Islam. Proceedings of the Regional Conference on Islamic Education, Shah Alam. 2010;1-14.

[Crossref]

15. Aziz AA, Ibrahim MA, Shaker MH, Nor AM. Teaching Technique of Islamic Studies in Higher Learning Institutions for Non-Arabic SpeakersExperience of Faculty of Quranic and Sunnah Studies and Tamhidi Centre, Universiti Sains Islam Malaysia. Universal J Educ Res. 2016;4(4)755-760.

doi: 10.13189/ujer.2016.040412 [Crossref]

16. No MCI-5(2)/2014-Med. Misc. /Medical Council of India. New Delhi, Executive Committee.

[Crossref] 